UDK 630*235: 632.95(497.6)

\title{
USE OF PETICIDES IN FOREST NURSERIES IN THE TERRITORY OF FEDERATION OF BOSNIA AND HERZEGOVINA
}

\section{Upotreba pesticida u šumskim rasadnicima na području Federacije Bosne i Hercegovine}

\author{
Tarik Treštić ${ }^{1}$, Osman Mujezinović ${ }^{1}$, Senada Osmić ${ }^{2}$
}

\begin{abstract}
Seedlings are produced by implementation of technical-technological procedures at specially prepared area which we call nurseries. With produced seedlings is additionally completed natural restoration of forests, forestation of bare lands, and plantations are established, melioration of degraded forest and brush-wood is conducted, eroded lands are repaired, etc. In the actual Registry of the Ministry of Agriculture, Water Management and Forestry of Federation of Bosnia and Herzegovina are registered 11 nurseries which produce forest and horticultural seedlings. In their production program dominant are three conifer tree species: Norway spruce (Picea abies), Scots pine (Pinus silvestris) and Black pine (Pinus nigra). Seedlings of broadleaves tree species in total production participate with only $2 \%$.

In nurseries is implemented the concept of integral protection of plants in the form of program which is consisted of combination of agrotechnical, mechanical, physical, biological and chemical measures. Chemical measures are based on the use of pesticides in integral protection of plants. Pesticides are organic and non-organic chemical compounds, as well as the products of living organisms which are used in agriculture and forestry for prevention of occurrence, control and suppression of caused of plant diseases, pest and weed, as well as for protection of agricultural and food products.

Main goal of this research was to identify the quantity indicators of use of pesticides in production of seedlings of forest trees in forest nurseries in Federation of Bosnia and Herzegovina. The research has covered three nurseries in Zenica-Doboj Canton and three nurseries in Central-Bosnia Canton. The research is related to the period from 2007 to 2011.
\end{abstract}

Key words: herbicide, fungicide, insecticide, seedlings, quantity indicators.

\footnotetext{
${ }^{1}$ Faculty of Forestry, Univeristy of Sarajevo

${ }^{2}$ Master of forestry, Zavidovići
} 


\section{INTRODUCTION - Uvod}

Seedlings are produced by implementation of technical-technological procedures at specially prepared area which we call nurseries. With produced seedlings is additionally completed natural restoration of forests, forestation of bare lands, and plantations are established, melioration of degraded forest and brush-wood is conducted, eroded lands are repaired, etc. In order to achieve the best possible results from forestation and to fulfill expert expectations, there were selected seedproduction facilities, collected and improved forest seeds, produced seedling of different tree species and implemented adequate technological procedures of preparation of the habitat and planting of seedlings. If we approach responsibly to each of the mentioned activities, we can expect that we will be able to grow and manage good quality of forest stands which will meet diverse needs of the people.

In the actual Registry of the Ministry of Agriculture, Water Management and Forestry of Federation of Bosnia and Herzegovina are registered 11 nurseries which produce forest and horticultural seedling material. In their production program dominant are three conifer tree species: Norway spruce (Picea abies), Scots pine (Pinus silvestris) and Black pine (Pinus nigra), which make about 97\% of totally produced seedlings. Out of the other seedlings of conifers produced are seedlings Douglas fir (Pseudotsuga menziesii) and European larch (Larix decidua) with about $1 \%$. Seedlings of broadleaves tree species in total production participate with only $2 \%$ (MEKIĆ ET AL., 2003; BALLIAN, 2000).

Main goal of nursery production is the production of quality seedlings which will meet the needs of the market with lowest possible mortality rate and acceptable production costs. Due to specifics of such production which are seen in production of large number of young plants in limited space, in nurseries are implemented intensive agrotechnical measures. However, these measures are not suitable only for grown plants but also for numerous harmful organisms. Therefore the nursery production is regarded as successful only when integral measures of plant protection are included in all activities conducted in nurseries.

Seedlings are subject to different harmful impacts of which the most important are the extreme weather conditions, weeds, plant diseases, harmful insects and other animals. With the intensive agrotechnical measures is tried to achieve and maintain the optimal conditions for growth and development of seedlings while for the harmful impacts, additionally, are implemented specific measures for their control and suppression.

According to the researches of HINDIJA (2006), the most represented species of weeds in forest nurseries are: Amaranthus retroflexus, Agropyron repens, Atriplex patula, Capsella bursa-pastoris, Chenopodium polyspermum, Cirsium arvense, Cynodon dactylon, Euphorbia helioscopia i Trifolium repens. Above the mentioned also present are the other species of weed plants: Agrostis stolonifera, Alopecurus myosuroides, Ambrosia artemisiifolia, Chenopodium album, Convolvulus arvensis, Cyperus sp., Datura stramonium, Digitaria sanguinalis, Echinochloa crus-galli, 
Erigeron canadensis, Galium aparine, Poa annua, Polygonum sp., Setaria sp., Sinapis arvensis, Solanum nigrum i Sorghum halepense (VASIC, 2012; OPALIČKI, 1992).

Plant diseases as harmful phenomena are present in all phases of production in forestry in seed-production facilities, nurseries, cultures and natural stands. The most represented group of causes of diseases is fungi, of which the following species are the most frequent: Amphisphaerella mycophila, Botrytis cinerea, Cyclaneusma niveum, Drepanopeziza punctiformis, Erysiphe alphitoides, Fusarium oxysporum, Lophodermella sulcigena, Lophodermium seditiosum, L. pinastri, Melampsora alliipopulina, Mycosphaerella pini, Phyllosticta paviae, Phytophthora sp., Rhizoctonia sp., Sphaeropsis sapinea $i$ Stigmina carpophila (LIOVIĆ, 2011; LJILJA ET AL., 2010; GlaVAŠ ET AL., 2009; LAZAREV ET AL., 2007; PEŠKOVA ET AL., 2007; LIOVIĆ AND ŽUPANIĆ, 2006; PoterI ET AL., 2005; GLAVAŠ, 2003; LAZAREV, 2000; USČUPLIĆ AND TREŠTIĆ, 2000; LJILJA ET AL., 1997; PAŠIĆ, 1985).

Of the other harmful organisms in nurseries significant place take harmful insects. Main damage is caused by larvae - wireworms (Elateridae) which survived the winter and which feed on seed, sprouts and roots of different broadleaves and conifers tree species. Larger damages are caused by leaf miners (Cameraria ohridella, Phyllonorycter platani, P. robiniella, Tischeria complanella,) and aphids (DAUTBAŠı́, 2000; LAZAREV, 2000).

In nurseries is implemented the concept of integral protection of plants in the form of program which is consisted of combination of agrotechnical, mechanical, physical, biological and chemical measures (POTERI ET AL., 2005). The goal of each program of integral protection of plants is to reduce abundance of populations of harmful organisms to the acceptable level and in that to be practically feasible, economically justifiable and without harmful consequences to grown plants, people and environment (ĐUKIĆ AND SEDLAR, 2003, JUNTUNEN, 2003). The base for the program of integral protection of plants is quality diagnosis for causes of the damages (MANGINI, 2012).

Chemical measures are based on the use of pesticides in integral protection of plants. Pesticides are organic and non-organic chemical compounds, as well as the products of living organisms which are used in agriculture and forestry for prevention of occurrence, control and suppression of caused of plant diseases, pest and weed, as well as for protection of agricultural and food products (MITRIĆ, 2012). However, for rational and optimal use of pesticides it is necessary to monitor and forecast development of populations of harmful organisms and timely beginning of protection (RAJKOVIĆ, 2013; MITRIĆ, 2012; DAUTBAŠIĆ, 2000; UsČUPLIĆ, 1981). Above that, it is important to apply selected pesticides with devices of new generation which have improved characteristics regarding the maintaining of hygiene, flushing-off, mixing and controlled treatment (ĐUKIĆ AND SEDLAR, 2003). That is in the same time the way to avoid unwanted effects and to make chemical protection more efficient and more favorable regarding ecological-toxic characteristics (BUDIMIR ET AL., 2005).

For suppression of weeds are used herbicide products based on different active ingredient (a.i.). In the use are mostly represented these a.i.: oxyfluorfen, trifluralin, 
dichlorprop, glyphosate, quinoclamine, nicosulfuron, primisulfuron, dazomet, terbuthylazine and hexazinone (VASIC ET AL., 2012; VASIĆ ET AL., 2010; GLAVAŠ ET AL., 2009; BudimiR ET AL., 2005, UsČUPLIĆ AND GLAVoČEVIĆ, 2003; JUNTUNEN, 2001; LAZAREV, 2000). Mentioned authors emphasize that the best effects in suppression of weeds are achieved by combination of herbicides based on different a.i.

Fungus, as main causes for diseases of seedlings are suppressed by fungicides in which content are present different a.i., like: metalaxyl, pirimethanil, benomyl, carbendazim, iprodione, propineb, thiram, maneb, famoxadone, fluazinam, captan, folpet, chlorothalonil, copper hydroxide, fenarimol, azoxystrobin, trifloxystrobin, propiconazole, triadimefon and cimoxanil (LIOVIĆ, 2011; GLAVAŠ ET AL., 2009; POTERI ET AL., 2005; JUNTUNEN, 2001).

For suppression of harmful insects are used insecticides in which content are the following a.i.: endosulfan, carbofuran, carbosulfan, triazamate, chlorpyrifos, dimethoate, diazinon, fenthion, chlormephos, oxydemeton-methyl, omethoate, alphacypermethrin, cyhalothrin, deltamethrin, permethrin, tetradifon, dazomet and triforine (GLAVAŠ ET AL., 2009; JUNTUNEN, 2001; LAZAREV, 2000).

Actual lists of pesticides, the distribution and use of which was approved in particular countries or in the territory of Europe, do not contain many of previously mentioned a.i. Prohibition of their use was prescribed based on the results of research by which is identified some of the harmful impacts to human health, animals of ecosystem as a whole. Status of particular a.i. can be checked on portals of national offices for plant protection (in Bosnia and Herzegovina - Department for plant health protection) and in European data base on pesticides (EU Pesticides Database).

Quantities of used pesticides are significantly different per years and nurseries. According to the researches in Finland, in forest nurseries in 1996 was used about $1000 \mathrm{~kg}$ of a.i. contained in different pesticides. In this quantity of pesticides, herbicides were presented with $42 \%$, fungicides with $40 \%$ and insecticides with $18 \%$. The highest quantity of pesticides was used in production of container seedlings of pine and lowest in production of spruce with bare root system. In production of seedlings with bare root system nurseries have applied and average of $3.9 \mathrm{~kg}$ of a.i./ha (JUNTUNEN, 2001). In USA, in production of seedlings with bare root system, the use of herbicides was $2.0 \mathrm{~kg}$ of a.i./ha, fungicides $2.9 \mathrm{~kg}$ of a.i./ha and insecticides $1.7 \mathrm{~kg}$ of a.i./ha (SOUTH AND ZWOLINKSI, 1996). On 1000 seedlings of all tree types was applied in average $2.16 \mathrm{~g}$ of a.i. of all pesticides (JUNTUNEN, 2001). According to the research of PERSSON (JUNTUNEN, 2001), the use of pesticides per 1000 seedlings in Sweden goes between $2.5 \mathrm{~g}$ a.i. (large nurseries with over 20 million seedlings) and $5.1 \mathrm{~g}$ a.i. (small nurseries with less of 5 million seedlings).

Main goal of these researches was to identify the quantity indicators of use of pesticides in production of seedlings of forest trees in forest nurseries in Federation of Bosnia and Herzegovina. 


\section{MATERIAL AND METHODS - Materijal i metode}

Research of indicators of production of seedlings of forest trees and use of pesticides in protection of their health was conducted in several phases. In the first step were analyzed and selected forest nurseries as the objects of research. Then were collected data on production of seedlings and use of pesticides. In third step were sorted and processed collected data. The research is related to the period from 2007 to 2011.

In selection of forest nurseries the attention was paid to their relevance in production of seedlings per quantity and quality and cooperation of personnel in conducting of this research. The research has covered three nurseries in Zenica-Doboj Canton (ZDC) and three nurseries in Central-Bosnia Canton (CBC). Basic information on objects of research are presented in the Table 1.

Table 1. Forest nurseries where the researches were conducted Tabela 1. Šumski rasadnici u kojima je provedeno istraživanje

\begin{tabular}{|l|c|c|c|c|}
\hline \multicolumn{1}{|c|}{ Forest nursery } & Canton & Established & $\begin{array}{c}\text { Productive area } \\
\text { (ha) }\end{array}$ & $\begin{array}{c}\text { Altitude } \\
\text { (m a s.l.) }\end{array}$ \\
\hline Ajdinovići, Olovo & ZDC & 1975. & 15.5 & 850 \\
\hline Potklečko polje, Zavidovići & ZDC & 1971. & 14.3 & 220 \\
\hline Lugovi, Žepče & ZDC & 1982. & 19.0 & 210 \\
\hline Busovača, Busovača & CBC & 1966. & 13.8 & 360 \\
\hline Lager, Bugojno & CBC & 1997. & 1.8 & 540 \\
\hline Travnik, Travnik & CBC & 1988. & 12.5 & 560 \\
\hline
\end{tabular}

In cooperation with nursery personnel were collected the following data:

- quantities of seedlings per main types of forest trees,

- quantities of used pesticides per chemicals prepared, and

- the most important problems in protection of vitality and health of seedlings of forest trees.

Average prices of used pesticides were calculated based on the price list of most important distributors in the region for the year 2009.

Based on the collected information on quantities of seedlings were identified total quantities of seedlings per groups of trees (conifers and broadleaves). By the insight into quantities and types of pesticide products were calculated total quantities of used a.i. per groups of pesticides (herbicides, fungicides, insecticides). Based on total quantities of a.i. and total quantity of seedlings were calculated average use of a.i. of particular groups of pesticides per 1000 seedlings, and after that also their total use. The use of a.i. pesticides was calculated also per hectare of productive area of researched nurseries.

Costs of procurement of pesticides were calculated based on quantities of used pesticide products and average prices per unit of product ( $\mathrm{kg}$ or 1$)$. After was 
calculated average amount which was spent for procurement of pesticides in $\mathrm{KM} / 1000$ seedlings.

\section{RESULTS - Rezultati}

Production of seedlings in nurseries in the period from 2007 to 2011 was presented as a sum for all researched nurseries, per groups of trees, years of production and as average for analyzed period (Table 2). Presentation of mentioned quantities is obtained based on the records from researched nurseries.

Table 2. Quantities of seedlings in researched forest nurseries

Tabela 2. Količine sadnica u istraživanim rasadnicima

\begin{tabular}{|l|r|r|r|r|r|r|r|}
\hline \multirow{2}{*}{$\begin{array}{c}\text { Groups of } \\
\text { trees }\end{array}$} & \multicolumn{5}{|c|}{ Quantities of seedlings per year (pieces) } & \multirow{2}{*}{$\begin{array}{c}\text { Average } \\
\text { (pieces) }\end{array}$} & \multirow{2}{*}{$\%$} \\
\cline { 2 - 8 } & 2007. & \multicolumn{1}{|c|}{2008.} & \multicolumn{1}{c}{2009.} & \multicolumn{1}{c}{2010.} & \multicolumn{1}{c}{2011.} & \\
\hline Conifers & 8682100 & 9610951 & 6007583 & 5084970 & 4249825 & 6727086 & 97.7 \\
\hline Broadleaves & 158700 & 176000 & 110280 & 243110 & 107510 & 159120 & 2.3 \\
\hline Total & 8840800 & 9786951 & 6117863 & 5328080 & 4357335 & 6886206 & 100.0 \\
\hline
\end{tabular}

Consumed quantities of pesticides in the period from 2007 to 2011 are presented as a sum for all nurseries, per pesticide groups, quantities of a.i. and as average for analyzed period. Presentation of quantities was obtained based on the records of researched nurseries on the used quantities of pesticides. Recalculating of quantities of pesticides into quantities of a.i. was conducted based on the content of a.i. in particular pesticide products (Table 3 ).

Table 3. Quantities of applied active ingredients (a.i.) pesticides per years

Tabela 3. Količine utrošenih aktivnih materija (a.m.) po godinama

\begin{tabular}{|c|c|c|c|c|c|c|c|}
\hline \multirow{2}{*}{ Pesticide } & \multicolumn{5}{|c|}{ Quantities of applied a.i. per year (kg or l) } & \multirow{2}{*}{$\begin{array}{l}\text { Average } \\
\text { (kg or } 1 \text { ) }\end{array}$} & \multirow{2}{*}{$\%$} \\
\hline & 2007. & 2008. & 2009. & 2010. & 2011. & & \\
\hline Herbicide & 372.65 & 327.28 & 395.40 & 394.44 & 388.28 & 375.61 & 58.6 \\
\hline Fungicide & 202.23 & 244.40 & 294.13 & 269.23 & 279.95 & 257.99 & 40.3 \\
\hline Insecticide & 3.34 & 3.21 & 8.81 & 10.98 & 8.08 & 6.88 & 1.1 \\
\hline Total & 578.22 & 574.89 & 698.34 & 674.65 & 676.31 & 640.48 & 100.0 \\
\hline
\end{tabular}

During production of seedlings following pesticide (active ingredient and product) are used:

a) herbicide: dazomet (Basamid granular), glyphosate (Cidokor $480 \mathrm{SL}$, Cosmic 36 /480 SL/, Glyphogan 480 SL, Herbocor 480 SL, Hercules 480 SL i Roundup), glufosinate (Basta 15), hexazinone (Velpar L), oxyfluorfen (Goal) and paraquat (Gramoxone $200 \mathrm{SL}$ ). The total quantities of a.i. dazomet was represented by about $80 \%$ and glyphosate with about $16 \%$. 
b) fungicide: captan (Captan WP 50, Merpan WP 50, Merpan WDG 70, Merpan WDG 80, Stoper WP 50), mancozeb (Dithan M 45, Ridomil Gold MZ 68 WG i Star WP 80), propineb (Antrakol WP 70) and zineb (Cineb S 65). The total quantities of a.i. captan was represented by about $75 \%$ and mancozeb with about $17 \%$.

c) insecticide: thiacloprid (Calipso $480 \mathrm{SC}$ ), methiocarb (Mesurol FS 50, Mesurol granulat) and deltamethrin (Decis 2,5 EC). The total quantities of a.i. thiacloprid was represented by about $47 \%$ and methiocarb with about $44 \%$.

d) Based on the data on quantities of a.i. used pesticides, quantities of seedlings and productive area of researched nurseries were calculated average use of a.i. pesticides per years, per 1000 seedlings and per ha of productive area. Data are presented in Table 4.

Table 4. Average use of a.i. pesticides

Tabela 4. Prosječna upotreba a.m. pesticida

\begin{tabular}{|l|r|r|r|r|r|r|}
\hline \multirow{2}{*}{ Indicator } & \multicolumn{5}{|c|}{ Year of production } & \multirow{2}{*}{ Average } \\
\cline { 2 - 7 } & \multicolumn{1}{|c|}{2007.} & \multicolumn{1}{|c|}{2008.} & \multicolumn{1}{|c|}{2009.} & \multicolumn{1}{c|}{2010.} & \multicolumn{1}{c|}{2011.} & \\
\hline Total kg a.i. & 578.22 & 574.89 & 698.34 & 674.65 & 676.31 & 640.48 \\
\hline Total seedlings & 8832800 & 9786951 & 6119363 & 5267580 & 4737485 & 6948836 \\
\hline g a.i./1000 sedlings & 65.46 & 58.74 & 114.12 & 128.08 & 142.76 & 92.17 \\
\hline kg a.i./ha & 7.52 & 7.48 & 9.08 & 8.77 & 8.79 & 8.33 \\
\hline
\end{tabular}

Based on the data on prices and quantities of used pesticides and quantities of seedlings was calculated the spent financial assets for procurement of it per years and per 1000 seedlings. Data are presented in Tables 5 and 6.

Table 5. Spent financial assets for procurement of pesticides

Tabela 5. Utrošak novčanih sredstava za nabavku pesticida

\begin{tabular}{|c|c|c|c|c|c|c|c|}
\hline \multirow{2}{*}{ Pesticide } & \multicolumn{5}{|c|}{ Spent financial assets for procurement of pesticides (KM) } & \multirow{2}{*}{$\begin{array}{c}\text { Average } \\
(\mathrm{KM})\end{array}$} & \multirow{2}{*}{$\%$} \\
\hline & 2007. & 2008. & 2009. & 2010. & 2011. & & \\
\hline П & 17446.50 & 14336.50 & 16690.00 & 16451.50 & 17514.30 & 16487.76 & 0 \\
\hline Fui & 126 & 15024.25 & 177 & 16750.80 & 17606.20 & $15 \mathrm{C}$ & 42.6 \\
\hline Ins & 13 & 1204.50 & 70 & 87 & 35.00 & 80 & 13.4 \\
\hline Total & 31412.00 & 30565.25 & 41435.00 & 41988.30 & 42005.50 & 37481.21 & 100.0 \\
\hline
\end{tabular}

Table 6. Average spent financial assets for procurement of pesticides

Tabela 6. Prosječni utrošak novčanih sredstava za nabavku pesticida

\begin{tabular}{|l|r|r|r|r|r|r|}
\hline \multirow{2}{*}{ Indicator } & \multicolumn{5}{|c|}{ Year of production } & \multirow{2}{*}{ Average } \\
\cline { 2 - 7 } & \multicolumn{1}{|c|}{2007.} & \multicolumn{1}{c|}{2008.} & \multicolumn{1}{c|}{2009.} & \multicolumn{1}{c|}{2010.} & \multicolumn{1}{c|}{2011.} & \\
\hline Total (KM) & 31412.00 & 30565.25 & 41435.00 & 41988.30 & 42005.50 & 37481.21 \\
\hline Total seedlings & 8832800 & 9786951 & 6119363 & 5267580 & 4737485 & 6948836 \\
\hline KM/1000 seedlings & 3.56 & 3.12 & 6.77 & 7.97 & 8.87 & 5.39 \\
\hline
\end{tabular}




\section{DISCUSSION - Diskusija}

Specific feature of production of seedlings is the growing of large number of young plants at limited area. By that feature such production has a lot of similarities with plant production in agriculture and vegetable production. Intensive agrotechnical measures which are regularly implemented in such production facilities are suitable not only for plants that are produced there but also to numerous harmful organisms. Therefore the nursery production will be successful to that proportion in which the integral plant protection measures are included in all activities which are conducted in nurseries (integral production).

Chemical measures are inevitable segment of integral protection of young plants in spite the fact that the use of pesticides is a risk for human health, animals and environment. In order to minimize the harmful effects of use of pesticides there is an effort to establish more efficient control of use of it. As the result of political measures in 90's of the last century there was recorded the reduction of the use of pesticides in majority of countries of Central and South-East Europe. However, in $21^{\text {st }}$ century is present increased use of it again (FAOSTAT). Due to that the members of EC have adopted a legal frame by which they are obliged to adopt national action plans for sustainable use of pesticides (NAP). Legal frame for adoption of NAP is contained in the Directive 2009/128/EC.

According to FAOSTAT, in European countries in 2010 for suppression of harmful organisms on arable land and in permanently planted areas were used pesticides in quantities of $0.35 \mathrm{~kg}$ a.i./ha (Montenegro) up to 8.75 a.i./ha (Netherlands). According to the NAP of Croatia, which was adopted for period 2013 to 2023, use of pesticides in 2010 was assessed, in this neighboring country, to $1.16 \mathrm{~kg}$ a.i./ha. In Serbia and Montenegro the use of pesticides is assessed to $0.74 \mathrm{~kg}$ a.i./ha (FAOSTAT, data for year 2004). For Bosnia and Herzegovina there are no data on use of pesticides.

According to the results of these researches in forest nurseries in Federation of Bosnia and Herzegovina the average use of pesticides was $8.33 \mathrm{~kg}$ a.i./ha of productive area. Compared to the use of pesticides in agriculture, this quantity is close to upper amount of use in countries of Central Europe and far above this statistical indicator in neighboring countries. Use of pesticides in researched forest nurseries is two times higher than in forest nurseries in Finland in 1996, and for about 20\% higher than in nurseries in USA (JUNTUNEN, 2001).

Use of pesticides is higher also per quantities of a.i. which are used in production of 1000 seedlings in forest nurseries of other countries. In nurseries in Finland, in 1996, in average was used $2.16 \mathrm{~g}$ a.i./1000 seedlings while in small nurseries in Sweden in average was used $5.1 \mathrm{~g}$ a.i./1000 seedlings (JUNTUNEN, 2001). Average use of pesticides in forest nurseries in Federation of Bosnia and Herzegovina according to this indicator was almost $92.17 \mathrm{~g}$ a.i./1000 seedlings. Such large differences can be the consequence of not enough accurate identification of quantities of produced seedlings in forest nurseries in Federation of Bosnia and Herzegovina. 
Therefore the assessment of the number of seedlings has to be conducted with increased attention and during that one should use scientifically based procedures. In the literature are mentioned some of the possibilities for analysis of quality variables during the use of method of sampling in nursery production and protection of plants (BALIĆ, 2000; ČABARAVDIć, 2000).

Quantities of used pesticides for protection of forest seedlings from harmful biotic agents depend on larger number of factors and they are significantly variable between particular nurseries and years of production. Among the factor which have particular impact to use of pesticides are tree species the seedlings of which are produced and their sensitivity to harmful effects of biotic agents, climate conditions during vegetation period, quality of the device for use of pesticides, quality of the protection program and achieved level of training of personnel for realization of it.

In the researched nurseries in Federation of Bosnia and Herzegovina mainly are produced seedling of conifers $(97.7 \%)$ among which the dominant is Norway spruce $(69 \%)$. Seedlings of Scotch pine are represented with about $20 \%$ and Black pine with about $8 \%$. Out of the seedlings of broadleaves tree species the most represented species are: European ash (34\%), sycamore (20\%) and sessile oak (17\%). In the protection of seedlings from harmful biotic agents the most used are herbicides $(58.6 \%)$ and then fungicides $(40.3 \%)$ and insecticides $(1.1 \%)$.

Heterogeneous production program probably has an impact to the proportion of quantities of used pesticides per groups. In nurseries in Slovakia in the period from 1996 to 1998, out of the totally treated area of all nurseries, herbicides were used at $50.3 \%$, fungicides at $41.4 \%$ and insecticides at $8.3 \%$ (KUNCA ET AL., 2007). In these nurseries broadleaves species of trees were represented with about $30 \%$ in total quantities of seedlings. In forest nurseries in Croatia in 2002, in which the seedlings of broadleaves species of trees were represented with about $67 \%$, the most used were fungicides and then insecticides and herbicides (GLAVAŠ, 2003). By analyzing the use of pesticides in the nursery Podbadanj in the period from 1993 to 2007, GLAVAŠ ET AL. (2009) have mentioned the following proportions per groups of pesticides: fungicides $49.8 \%$, zoocides $29.3 \%$ and herbicides $20.9 \%$. Authors have identified the increased use of pesticides during the analyzed period.

The approach in suppression of weed in researched nurseries in Federation of Bosnia and Herzegovina is based on disinfection of the land and extermination of their reproductive organs before and after planting of seed. During vegetation period this measure is supplemented with mechanical removal of weed and limited use of herbicides. Therefore the share of dazomet as a.i. with about $80 \%$ and glyphosate with about $16 \%$ in total quantities of a.i. herbicides was expected. The implemented combination of chemical and mechanical suppression of weed is good solution also according to the opinion of other researchers (VASIĆ ET AL., 2012, 2010; UsČUPLIĆ AND GLAVOČEVIĆ, 2003: LAZAREV, 2000).

The share of conifers with $97.7 \%$ in total quantities of seedlings in researched forest nurseries in Federation of Bosnia and Herzegovina, is extremely unfavorable regarding the occurrence of Damping off disease. On the other hand, if we analyze the 
impact of produced assortment to the occurrence of disease on older seedlings, then the large share of applied pesticides can be assessed as favorable (spruce is less sensitive to diseases) while larger share of pines and sessile oak could be unfavorable circumstance due to occurrence of diseases: needle cast and powdery mildews. Therefore the large use of fungicides in total quantities of pesticides is expected.

Insecticides were used in the researched nurseries mostly for suppression of larvae - wireworms (Elateridae) and mole-cricket. Lower use of these chemicals has to be observed in the context of applied pesticides for disinfection of the land. During that, along with its herbicide and fungicide effects were also present its effects as insecticide. The quantity of a.i. which was used in researched nurseries in average was about $47 \%$ a.i. of all pesticides together.

The weather during the vegetation period can have significant impact to the quantities of used pesticides. Years in which, in shorter periods of time, change sunny periods and rain periods one after the other, are suitable for development of growing of weed and development of diseases. Except that, the apply of pesticides has to be repeated in case that after the treatment and before the expired minimal necessary time was raining and due to the effects of it were reduced. According to the research of GLAVAŠ ET AL. (2009) which was realized in forest nursery Podbadanj in Croatia, the average number of treatments with fungicides was 7.5 times per year, with zoocides 4.3 times per year and with herbicides 3.1 times per year (an average for all pesticides was 15 times per year).

The quality of the device for apply of pesticides has to be in compliance with the requests of the producer of pesticides because otherwise there can be absent or reduced the efficiency of the implemented product. The researcher are pointing out to this problem and they emphasize that with the new generation of devices for apply of pesticides can be achieved better coverage of treated surfaces and more even distribution of a.i. a time and better efficiency of pesticides (ĐUKIĆ AND SEDLAR, 2003). Probably this is also one of the reasons due to which the use of pesticides in researched nurseries in Federation of Bosnia and Herzegovina is significantly higher than in nurseries in other countries.

Good quality of the program of protection of seedlings in forest nurseries has to be based on combination of all available measures in the control and suppression of harmful agents (administrative, agrotechnical, mechanical, physical, chemical and biological measures). With such approach can be achieved an optimal use of pesticides and avoided majority of harmful/unwanted effects. Further rationalization of the use of pesticides is possible also by timely apply of particular compounds which will be based on good quality of monitoring and forecasting of development of harmful agents. Forest nurseries in that sense have to be equipped with necessary equipment for monitoring of weather indicators, especially during the vegetation period. Based on this monitoring it is possible to more precisely designate the beginning of suppression of harmful agents (RAJKOVIĆ ET AL., 2013).

A good quality of records of all information related to integral production and protection of seedlings in forest nurseries could offer answers and explanations on the 
reasons for increased use of pesticides. According to the results of these researches the quantity of seedlings in 2011 was half lower than the quantity in 2007. However, reduction of the seedlings production did not result in lower use of pesticides, which should be expected, but the use was even increased. Records on this would be useful also for the analysis of spent financial assets for procurement of pesticides. For this purpose in average was spent about $37500 \mathrm{KM} /$ per year. Calculated into 1000 seedlings, the cost for procurement of pesticides in the researched period was $3.12-$ $8.87 \mathrm{KM} / 1000$ seedlings (in average $5.39 \mathrm{KM} / 1000$ seedlings).

These are first researches of quantity indicators of use of pesticides in forest nurseries in Federation of Bosnia and Herzegovina. By this was achieved a frame insight into use of pesticides and the costs of procurement of it. In further researches we should try to identify, above the quantity indicators, also the quality indicators of the use of pesticides as well as the other measures of integral protection. Based on that we could approach to the making of calculations of production of seedling of the most important species of forest trees and also point out to the possibility of more rational use of pesticides.

\section{Acknowledgement - Zahvala}

The authors wish to thank to the local forestry staff from the forest enterprises and nurseries for their support. We sincerely thank the colleagues: Hatidža Zečević, Alma Ćurić, Aida Degirmendžić, Niko Čavara, Ivica Murlin, Aladin Tuco and Salem Gurda for providing all necessary data.

\section{REFERENCES - Literatura}

BALIĆ, B. (2000): Statistička procedura analize kvalitativnih varijabli pri upotrebi metode uzorka u rasadničkoj proizvodnji i zaštiti bilja. Savjetovanje o »Sjemensko-rasadničkoj proizvodnji u šumarstvu BiH - stanje i perspektive«, Brčko, Zbornik radova, str. 105-112.

BALLIAN, D. (2000): Značaj rasadničke proizvodnje za održavanje i povećanje biodiverziteta šuma. Sjemensko-rasadnička proizvodnja u BiH - Stanje i perspektiva. Brčko, str: 81-83.

BudimiR, M., RadivojeVIĆ, LJ., BRKIĆ, D. I NeŠKović, N. (2005): Ekotoksikološka svojstva herbicida: Sulfoniluree. Institut „Srbija“, Centar za pesticide i zaštitu životne sredine Beograd-Zemun. Pesticidi i fitomedicina 20, str: 153-161.

ČABARAVDIĆ, A. (2000): Primjena statističkih metoda u sjemensko-rasadničkoj proizvodnji. Savjetovanje »Sjemensko-rasadnička proizvodnja u šumarstvu $\mathrm{BiH}-$ stanje i perspektive«, Brčko, Zbornik radova, str. 99-103. 
DAUTBAšı́, M. (2000): Štetni insekti u šumskim rasadnicima u Federaciji Bosne i Hercegovine. Savjetovanje »Sjemensko-rasadnička proizvodnja u šumarstvu BiH - stanje i perspektive«, Brčko, Zbornik radova, str. 123-126.

Đukić, N. I SedlaR, A. (2003): Prskalice nove generacije. Savremena poljoprivredna tehnika Vol. 29, No. 3, p. 69-136.

GLAVAŠ, M. (2003): Zdravstveno stanje biljaka i mjere zaštite u šumskim rasadnicima u Hrvatskoj u 2002. godini. Šumarski list br. (127) 5-6: 257-268.

GLAVAŠ, M., GLAVAŠ, S., BUDIŠĆAK, M. I VUKADIN A. (2009): Štetočinje i zaštita biljaka u rasadniku „Podbadanj“ od 1993. do 2007. godine. Sumarski list br. (133) 11-12: 623-628.

HINDIJA, N. (2006): Primjena herbicida na najzastupljenije korovske vrste u rasadnicima šumskih i ukrasnih sadnica. Zbornik rezimea, III Simpozijum o zaštiti bilja u Bosni i Hercegovini, Neum, 13-15. decembar 2006. godine.

JUNTUNEN M-L. (2003): Environmental impacts of nurseries. In: Riley L.E., Dumroese R.K., Landis T.D., technical coordinators. National Proceedings: Forest and Conservation Nursery Associations. Ogden, UT: USDA Forest Service, Rocky Mountain Research Station. Proceedings RMRS-P-28: 64-73.

JUNTUNEN, M-L. (2001): Use of pesticides in Finnish forest nurseries in 1996. Silva Fennica 35(2): 147-157.

Kunca, A., LeONTOVYČ, R., ZÚBRIK, M., V. LONGaUerovÁ, V. AND FoffovÁ, E. (2007): Occurrence of pests in Slovak forest nurseries from 1990 to 2004. In: Diseases and insects in forest nurseries - The sixth meeting of the IUFRO Working Party 7.03.04. Editors: J. R. Sutherland, Z. Procházková. Communicationes Instituti Forestalis Bohemicae, Vol. 23: 96-102.

LAZAREV, V. (2000): Biotički uzročnici šteta u rasadnicima RS i mjere zaštite. Sjemenskorasadnička proizvodnja u BiH - Stanje i perspektiva. Brčko, str: 117-122.

Lazarev, V., KaradžIC, D., Marković, M., PaP, P. and Poljaković-Pajnik, L. (2007): The Most Frequent Lophodermium spp. on Scots Pine and Austrian Pine and Their Role in the Appearance of Other Fungi on the Needles. Acta Silv. Lign. Hung., Spec. Edition, 53-59.

LILJA, A., LILJA, S., KURKELA, T. AND RIKALA, R. (1997): Nursery practices and management of fungal diseases in forest nurseries in Finland. A review. Silva Fennica 31(1): 79-100.

Lilja, A., Poteri, M., Petäistö, R.-L., Rikala, R., Kurkela, T. and Kasanen, R. (2010): Fungal diseases in forest nurseries in Finland. Silva Fennica 44(3): 525-545.

LıOVIĆ, B. (2011): Utjecaj pepelnice (Microsphaera alphitoides Grift. et Maubl.) na rast i preživljenje hrastova ponika. Šumarski list (135) poseban broj: 122-129.

LıOvIĆ, B. I ŽUPANIĆ, M. (2006): Ispitivanje djelotvornosti fungicida za suzbijanje gljive Microsphaera alphitoides Griff et Maubl. na hrstovom pomlatku. Rad. Šumar. inst. Izvanredno izdanje 9: 181-188. 
MANGINI, A.C. (2012): Diagnosis of pest problems. In: Forest Nursery Pests, USDA, Agriculture Handbook No. 680, pages: 1-4.

MekiĆ, F., Ballian, D., VIŠnjIĆ, Ć. I KARKELJA, E. (2003): Stanje i perspektive proizvodnje sadnog materijala u rasadnicima Federacije Bosne i Hergcegovine. Zbornik radova, Šumarski fakultet Univerziteta u Sarajevu, Sarajevo.

MITRIĆ, S. (2012): Priručnik za primjenu fitofarmaceutskih sredstava sa pregledom obaveza korisnika i preporukama dobre poljoprivredne prakse. Grafomark, Laktaši, 1-59.

OPALIČKI, K. (1992): Primjena FFS u Hrvatskoj tijekom 1990. godine. Šumarski list br. (116) 6-8: 283-289.

PAšıć, M. (1985): Prilog poznavanju uzročnika polijeganja ponika u šumskim rasadnicima SR BIH. Šumarstvo i prerada drveta, Sarajevo br. 7-9, str: 257-396.

PeŠKovÁ, V., SoukuP, F. AND KAPITOLA, P. (2007): Biotic damaging agents in forest nurseries in the Czech Republic. In. Diseases and insects in forest nurseries - The sixth meeting of the IUFRO Working Party 7.03.04. Editors: J. R. Sutherland, Z. Procházková. Communicationes Instituti Forestalis Bohemicae, Vol. 23: 138.

Poteri, M., A. LILJA, A. AND PetÄIStö, R.-L. (2005): Control of nursery diseases and pests in Finnish forest tree nurseries. Working Papers of the Finnish Forest Research Institute 11, 19-26.

RAJKOVIC, S., MARKOVIC, M. AND RAKONJAC, LJ. (2013): Incubation Methods for Forecasting the Occurrence and Development of Lophodermium seditiosum Minter, Staley \& Millar on Pine. In: Fungicides - Showcases of Integrated Plant Disease Management from Around the World. Edited by Mizuho Nita, ISBN 978-953-51-1130-6, 153-182 pages, Publisher: InTech, Chapters published May 15, 2013 under CC BY 3.0 license.

SoUtH, D.B., ZWolINKSI, J.B. (1996): Chemicals Used in Southern Forest Nurseries. Southern Journal of Applied Forestry, 20 (3): 127-135.

UsČUPLIĆ, M. (1981): Infekcioni period Lophodermium seditiosum Min., Stal. and Mill, i mogućnosti njegovog suzbijanja u rasadnicima. Zaštita bilja, 32(4): 375-382.

USČUPLIĆ, M. I TREŠTIĆ, T. (2000): Bolesti sjemena i sadnica u šumskim rasadnicima. Savjetovanje »Sjemensko-rasadnička proizvodnja u šumarstvu BiH - stanje i perspektive«, Brčko, Zbornik radova, str. 113-116.

USČUPLIĆ, M. I GLAVOČEVIĆ, F. (2003): Zaštita od korova u šumskim rasadnicima. Herbologija, ANUBiH, Sarajevo, Vol. 4, No 1, str. 133-140.

VASIĆ, V., GALIĆ, Z. I DREKIĆ, M. (2010): Učinkovitost i selektivnost nekih herbicida u rasadničkoj proizvodnji sadnica topola. Šumarski list br. (134) 7-8: 395-401.

VAsic, V., KonstantinOVIC, B. AND ORLOVIC, S. (2012): Weeds in Forestry and Possibilities of Their Control. In: Weed Control. Edited by Andrew J. Price, ISBN 978-953-51-0159-8, 276 pages, Publisher: InTech, Chapters published February 29, 2012 under CC BY 3.0 license. 


\section{SAŽETAK}

Mješovite raznodobne šume sa prirodnom obnovom čine najveći dio šumskog fonda u Bosni i Hercegovini. Sadnja sadnica (pošumljavanje) se primjenjuje s ciljem dopune prirodne obnove ili podizanja novog zasada u slučajevima kada matična sastojina to ne omogućava, odnosno kada iz bilo koji razloga nismo zadovoljni sa aktuelnim korištenjem potencijala nekog šumskog staništa.

U aktuelnom Registru Ministarstva poljoprivrede, vodoprivrede i šumarstva u Federaciji Bosne i Hercegovine $(\mathrm{FBiH})$ je uvedeno 11 rasadnika koji proizvode šumske i ukrasne sadnice. U njima se uglavnom proizvode tri vrste četinara (oko 97\%): smrča (Picea abies), bijeli bor (Pinus sylvestris) i crni bor (Pinus nigra) i nekoliko ostalih četinarskih (1\%) i lišćarskih vrsta (2\%).

Prilikom proizvodnje u rasadnicima, sadnice su izložene različitim štetnim uticajima biotskih i abiotskih faktora. Radi otklanjanja ili smanjivanja ovih uticaja u rasadnicima se primjenjuje koncept integralne zaštite biljaka u vidu programa kojeg čine kombinacije agrotehničkih, mehaničkih, fizičkih, bioloških i hemijskih mjera a s ciljem kontrole brojnosti populacija štetnih organizama. Hemijske mjere zaštite podrazumijevaju samo jedan segment integralne zaštite biljaka. Osnov hemijskih mjera jeste primjena pesticida. Pesticidi (fitofarmaceutska sredstva ili sredstva za zaštitu bilja) su organska i neorganska hemijska jedinjenja, kao i produkti živih organizama koje se koriste u poljoprivredi i šumarstvu za prevenciju pojave, kontrolu i uništavanje uzročnika biljnih bolesti, štetočina i korova, kao i zaštitu poljoprivrednih i prehrambenih proizvoda.

Cilj ovog rada bio je istražiti količinske pokazatelje hemijske zaštite u proizvodnji sadnica šumskog drveća. Istraživanjima je obuhvaćen period od pet godina (2007.-2011. godina) a provedena su u šest rasadnika u $\mathrm{FBiH}$. Na osnovu prikupljenih podataka utvrđene su količine proizvedenih sadnica i količine utrošenih pesticida.

U rasadnicima koji su obuhvaćeni istraživanjem u periodu od 2007. do 2011. godine u različitim fazama proizvodnje zatečeno je ukupno 33.635 .429 sadnica četinara i 795.600 sadnica lišćara (tabela 2). Prema rezultatima ovih istraživanja korovi predstavljaju najznačajniji problem u rasadničkoj proizvodnji. U periodu od pet godina primijenjeno je $1.878,05 \mathrm{~kg}$ ili 1 a.m. herbicida $(58,6 \%$ od ukupne količine a.m.). Za suzbijanje bolesti upotrijebljena je količina od $1.289,94 \mathrm{~kg}$ ili 1 a.m. fungicida (40,3\% od ukupne količina a.m.). Za suzbijanje štetnih insekata upotrijebljeno ukupno je 34,42 kg ili 1 a.m. insekticida (1,1\% od ukupne količina a.m.) (tabela 3). Najveća novčana sredstva izdvojena su za kupovinu herbicida, prosječno $16487,76 \mathrm{KM} /$ godišnje $(44,0 \%)$. Za kupovinu fungicida je izdvojeno u prosjeku $15956,65 \mathrm{KM} /$ godišnje $(42,6 \%)$ i za za kupovinu insekticida $5.036,80 \mathrm{KM} /$ godišnje $(13,4 \%)$ (tabela 5). 